論文受付

2019 年 3 月 11 日

論文受理

2020 年 3 月 17 日

Code No. 261

\section{自動解析ツールを用いた \\ 放射線治療計画用 MRI の経時的な歪み評価}

笹本耕平 ${ }^{1}$ 金本雅行 ${ }^{1} \quad$ 石田翔太 $^{1} \quad$ 嶋田真人 $^{1}$ 木村浩彦 $^{1} \quad$ 安達登志樹 ${ }^{2}$

\author{
1 福井大学医学部附属病院 \\ 2 新潟医療福祉大学医療技術学部診療放射線学科
}

\section{緒 言}

近年, 放射線治療計画に扮いて, computed tomography $(\mathrm{CT})$ 画像だけでなく magnetic resonance (MR) 画像や positron emission tomography (PET) 画像など との image fusion を行うことが一般的になってきて いる ${ }^{1,2)}$. 特に MR 画像は組織コントラストに優れ, CT 単独の場合と比較して肉眼的腫瘍体積 (gross tumor volume: GTV) や危険臟器 (organ at risk: OAR) な どが同定しやすくなるため利用されることが多 ( ${ }^{1,2)}$. しかしながら MRIには静磁場不均一や傾斜磁 場の非直線性, 被写体が不均一であることによる磁場 の不均一などが原因となり画像に幾何学的な歪みが存
在することが知られており ${ }^{3,4)}$ ，使用にあたってはその 程度を確認するために幾何学的な歪みの把握が必要に なる ${ }^{5,6)}$.

CT 装置には放射線治療計画用装置としての quality assurance (QA) ガイドラインが存在しており に従い管理を行うことができる。一方，MR装置には 治療計画用装置としての QA ガイドラインは現状存 在せず, American Association of Physicists in Medicine (AAPM) や National Electrical Manufacturers Association(NEMA)の診断装置用としてのQA を記 したレポートなどが参考となる. A APM の task group (TG) 1 Report NO 1008) では放射線治療計画用

\title{
Evaluation of Long-term Fluctuation of Geometric Distortion in MRI for Radiation Therapy Planning by Using an Automatic Analysis Tool
}

\author{
Kouhei Sasamoto, ${ }^{1 *}$ Masayuki Kanamoto, ${ }^{1}$ Syouta Ishida, ${ }^{1}$ Masato Shimada, \\ Hirohiko Kimura, ${ }^{1}$ and Toshiki Adachi $^{2}$ \\ ${ }^{1}$ University of Fukui Hospital \\ ${ }^{2}$ Department of Radiological Technology, Niigata University of Health and Welfare
}

Received March 11, 2019; Revision accepted March 17, 2020

Code No. 261

\section{Summary}

High tissue contrast in magnetic resonance imaging (MRI) allows better radiotherapy planning. However, geometric distortion in MRI induces inaccuracies affecting such planning, making it necessary to evaluate the characteristics of such geometric distortion. Although many studies have considered geometric distortion, most of these involved measurements performed only a few times. In this study, we evaluated MRI device-specific geometric distortion over long term and measured its variation by using an automatic analysis tool. The result showed that geometric distortion increased with distance from the center along both lateral and longitudinal directions. Specifically, the average distortion rate and average diameter error over the full measurement period increased by up to $1.02 \%$ and $1.96 \mathrm{~mm}$, respectively, when using $\mathrm{T}_{1}$ weighted Image (WI) 3D fast spoiled gradient echo (FSPGR) at R15. In the case of $\mathrm{T}_{2}$ WI 2D fast spin echo (FSE) at R15, the standard deviation of the distortion rate and diameter error increased up to $0.38 \%, 0.72 \mathrm{~mm}$, respectively. We conclude that periodic quality assurance of geometric distortion should be performed in order to maintain geometric distortion within allowable values.

Keywords: magnetic resonance imaging (MRI), geometric distortion, off-center, radiation therapy

*Corresponding author 

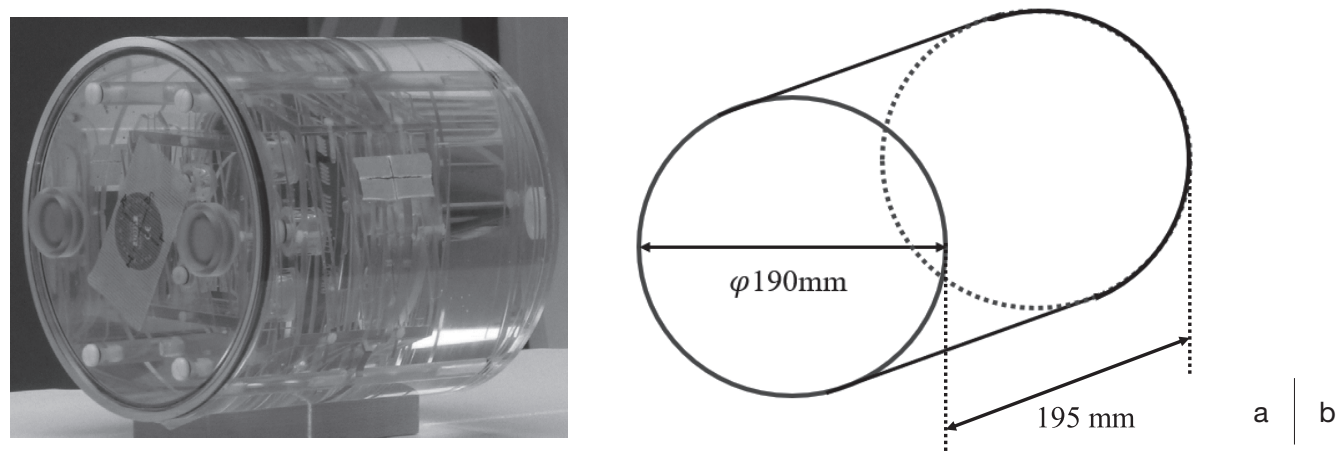

Fig. 1 Structure of Magphan.

(a) Outside appearance of Magphan, (b) Inside dimension of Magphan

MRI としての歪みの許容值を ACR ファントム (ファ ントム直径 $190 \mathrm{~mm}$ )を使用した場合，ファントム直径 の公称值と測定值の差を, 変化率と径誤差でそれぞれ 2.0\%，2.0 mm と定めているため，ユーザはこの值を 超えないように経時的な QA を行い, 管理する必要が ある。

またここ数年, 独自の方法で幾何学的な歪みについ て検討された報告がいくつか出てきており，Pappas $ら^{5)}$ は頭部を想定した範囲での歪みの解析を行い,

ターゲットのサイズと位置のオフセットを組み合わせ て治療計画の評価指標である $95 \%$ 体積線量 $\left(D_{95}\right)$ や原 体性指数 (conformity index: CI) の変化について報告し ている。またTorfeh ら ${ }^{6)}$ は MR 装置のベンダが供給 するファントムを用いて field of view $(\mathrm{FOV}) 50 \mathrm{~cm}$ の 範囲内でのオフセンタにおける歪みの大きさを報告し ている。しかしながら, これら研究の中で報告されて いる值は単回あるいは小数回のデータであり，経時的 な情報については含まれていない，QAの許容值など を定める際などには真值と測定值の誤差は重要である が，時間軸での值の変化も考慮する必要がある。また Wyatt ${ }^{9)}$ は, 装置 QA において商用のファントムと 解析ソフトウェアを使用する場合, 臨床での使用前に その精度を検証する必要があるとしている。本検討で は，この経時的な值の変化を測定するために商用の MRI 性能評価ファントムである Magphan(AQUILAB, France)に加えて, 解析装置として自動解析が可能な $\operatorname{ARTISCAN}(\mathrm{AQUILAB})$ を用いている. Magphan に ついてはファントムサイズの公称值が示されているも のの, 解析装置である ARTISCAN の自動解析の精度 については明示しているデータが存在しない.

そこで本研究の目的として, Magphanおよび ARTISCAN の解析精度を NEMA 法との比較測定を した上で，それらを用いて画像の幾何学的な精度に影
響を及ぼす幾何学的歪みについての経時的な変化を， 当院の治療計画用 MRI 撮像シーケンスで検討した。

\section{1. 方 法}

本研究では, MRI 性能評価ファントムである Magphan および解析装置である ARTISCAN を用い た.このファントムは Fig. 1 に示すように直径 190 $\mathrm{mm}$ のファントムで, さまざまな物理特性の解析モ ジュールが挿入されており, 一度の撮像で signal to noise ratio (SNR) や均一性, 歪み, スライス厚などの 評価ができる円柱型のファントムである。ファントム 内部は $10 \mathrm{mM}$ 塩化ニッケル水溶液 $\left(\mathrm{T}_{1}\right.$ 值 $145 \mathrm{~ms}, \mathrm{~T}_{2}$ 值 $146 \mathrm{~ms}$ ) で満たして使用した。今回は解析項目の中 から CTとの比較が可能, かつ放射線治療における治 療計画の精度に影響を及ぼすと考えうる幾何学的歪み を測定することとした。

まず基準となるデー夕を取得するために Magphan を治療計画用 CT (SOMATOM Sensation Open; Siemens Healthineers, Germany)を用いて管電圧 120 $\mathrm{kV}$, 管電流 $130 \mathrm{~mA}$ ，検出器数と幅 $20^{*} 0.6 \mathrm{~mm}$, ピッ チ $0.7 \mathrm{~s}$ ，回転時間 $1.0 \mathrm{~s}$ で撮影した。撮影したaxial, sagittal, coronal 画像上にグリッド線を表示させ, Fig. 2a-c に示すように Magphan 内部のモジュールが axial では対向, sagittal, coronal では矢印で示すように一 直線となることを観察し, pitch(sagittal 面の回転), yaw (coronal 面での回転), roll(axial 面での回転)方向 の傾きがないことを確認した。 このとき, ファントム の中心に治療計画用 CT のレーザを用いて基準線を引 き, 以後行う MRI 撮像の際の位置合わせに用いた。 なお， CT の撮影はこの基準データ取得の際の 1 回の みとした

MRI 撮像は診断用 MRI 装置(Optima MR 450w; GE Healthcare, USA) を用いて行った。本装置には外付け 

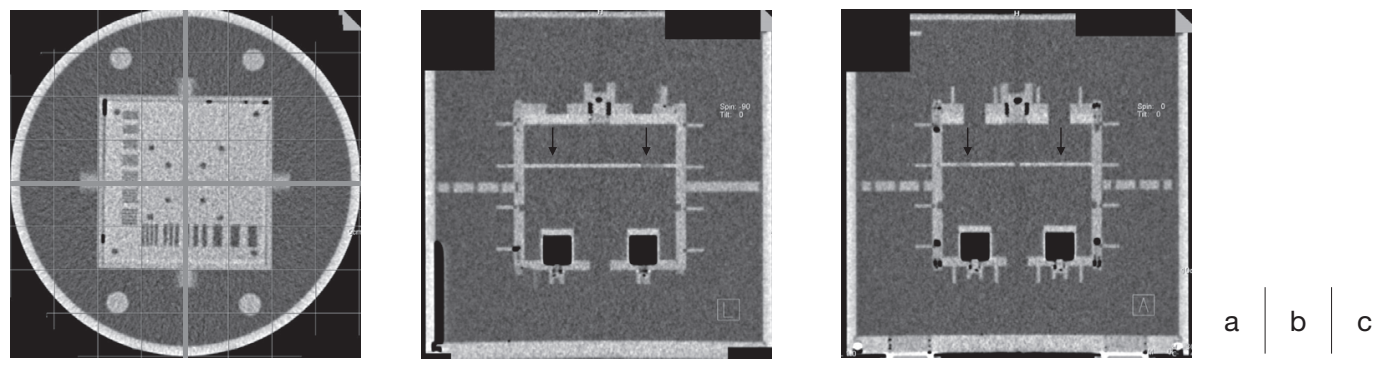

Fig. 2 Set up of Magphan in CT.

(a) Axial plane of Magphan, (b) Sagittal plane of Magphan, (c) Coronal plane of Magphan

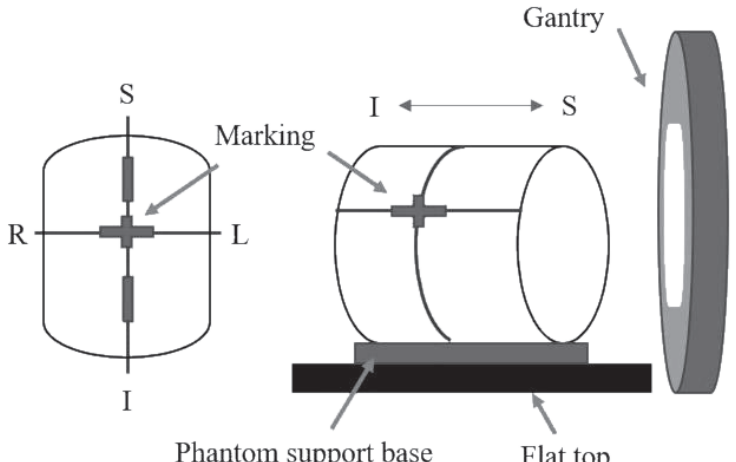

Phantom support base Flat top
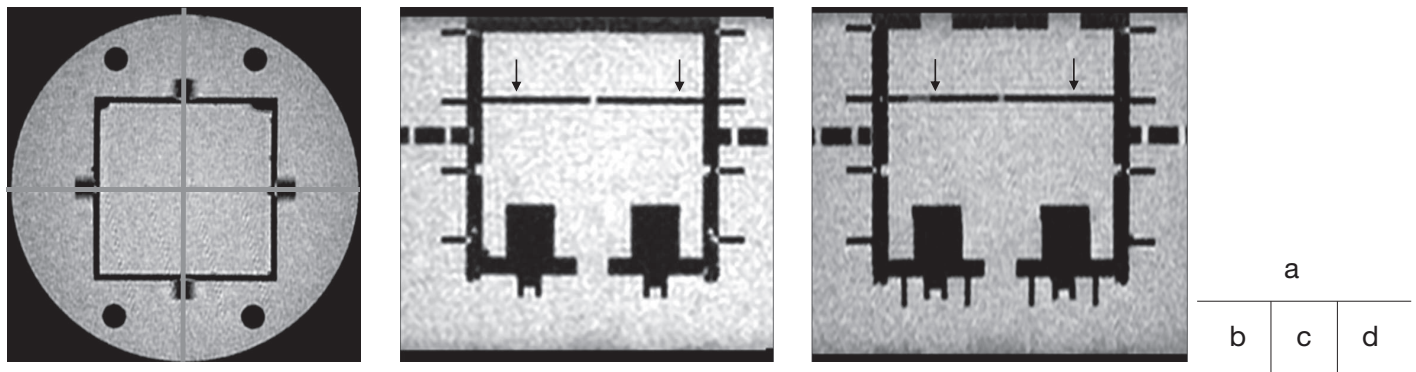

Fig. 3 Set up of Magphan in MRI.

(a) Alignment of Magphan, (b) Axial plane of Magphan, (c) Sagittal plane of Magphan,

(d) Coronal plane of Magphan

レーザーシステム(TAKENAKA OPTNIC, 京都)を導 入しており，本レーザで Fig. 3aのようにCT 撮影時 に書いた基準線を用いてファントムの位置合わせを 行った。 続いて, Fig. 3b-d に示すように MRIの撮像 前にもCT と同様の方法で pitch, yaw, roll 方向の傾 きがないことを確認した，撮像コイルはファントム設 置の際に上記の位置合わせ用レーザが視認できなくな るため, 装置内蔵の body coil とした.

\section{1-1 ARTISCAN の解析精度の計測}

ARTISCAN による解析精度を確認するために，ま ずMRI の歪み測定に一般的に用いられている NEMA 法に準じたファントムおよび撮像シーケンスである spin echo(SE)を用いて, axial 断面での幾何学的歪み の測定を行った。使用したファントムは ACR MR accreditation phantom (American College of Radiology,
USA)で，ファントム直径は $190 \mathrm{~mm}$ である。内容液 は Magphan に充填したものと同じ $10 \mathrm{mM}$ 塩化ニッ ケル水溶液とした。撮像条件は TR $500 \mathrm{~ms}$, TE 10 $\mathrm{ms}$ ，スライス厚 $10 \mathrm{~mm}$, FOV $256 \mathrm{~mm}$, マトリクス： 256×256 とした。撮像した画像をコンソール上の Viewer で開き, Fig. 4a に示すように測定間隔が $45^{\circ}$ 以下となるように 4 カ所のファントム直径を測定し た。続いて同撮像条件で Magphan を撮像し, Fig. 4b のようにMagphan を ARTISCAN で解析した際の直 径と比較を行ったＡARTISCANの自動解析では，ハ フ変換によってファントム輪郭を抽出し，ファントム の中心を認識し，ファントム中心を通る線を 4 本引 き，それぞれプロファイルを取得し，その半值幅を直 径として測定した. NEMA 法ではファントムに大き な歪みが生じた際に, ファントム中心の認識が困難と なるため, オフセンタでの歪みの測定が難しくなる. 

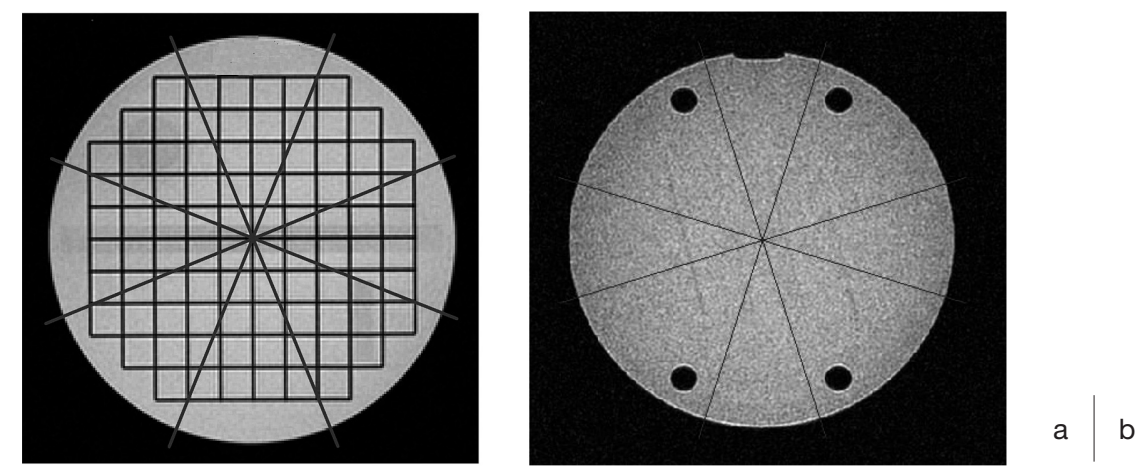

Fig. 4 Line segment setting method for measurement of inner diameter distance. (a) Setting of inner diameter distance used for distortion analysis by using NEMA method and ACR phantom.

(b) Setting of inner diameter distance used for distortion analysis by using ARTISCAN and Magphan phantom.

Table 1 Imaging sequences with MRI system

\begin{tabular}{lccc}
\hline \hline & $\mathrm{T}_{1}$ WI 3D FSPGR & $\mathrm{T}_{2}$ WI 3D Cube & $\mathrm{T}_{2}$ WI 2D FSE \\
\hline FOV (mm) & 260 & 260 & 260 \\
TR (ms) & 8.5 & 3000 & 4296 \\
TE (ms) & 3.9 & 102 & 102 \\
slice thickness (mm) & 1.4 & 2.0 & 3.0 \\
Number of slices (slices) & 172 & 60 & 34 \\
ETL & - & 100 & 11 \\
Matrix (frequency*phase) & $288 * 192$ & $320 * 320$ & $320 * 256$ \\
Freq. direction & $\mathrm{RL}$ & $\mathrm{RL}$ & $\mathrm{RL}$ \\
Bandwidth (Hz/pixel) & 25.00 & 35.71 & 31.25 \\
3D geometry collection & + & - & - \\
\hline
\end{tabular}

そのため NEMA 法と ARTISCAN の比較は静磁場中 心でのみ行った

\section{1-2 幾何学的歪みの経時的な変化の測定}

上述のように axial, sagittal, coronal の 3 断面の画 像を用いて Magphanのセットアップを行い，撮像を 行った，撮像には当院の頭部および前立腺用のプロト コルで用いているシーケンスを使用した，頭部の撮像 に使用する $\mathrm{T}_{1} \mathrm{WI} 3 \mathrm{D}$ fast spoiled gradient echo (FSPGR), 前立腺の撮像に使用する $\mathrm{T}_{2} \mathrm{WI} 2 \mathrm{D}$ fast spin echo (FSE), $T_{2}$ WI $3 \mathrm{D}$ variable refocusing flip angle fast spin echo; Cube(FSE Cube)を使用した。撮 像パラメータを Table 1 に示す. 3D シーケンスには ベンダから提供されている3D geometry correction を用いることができるため， T 1 WI 3D FSPGR に併用 した. 3D geometry correction は GE Healthcare 社の 装置に内蔵されている歪み補正アルゴリズムである. 傾斜磁場の非直線性により, ある信号の位置にはズレ が生じるが，そのズレ量が理想的な位置に対してどの
程度であるかを予測し，補正することで歪みを補正す るという歪み補正法である ${ }^{10)}$.

静磁場中心での撮像の後, ファントム内の歪み測定 位置を基準として, Fig. 3a に示すように体軸方向ガン トリ側 (S 方向)に $5 \mathrm{~cm}$ 間隔で $15 \mathrm{~cm}$ までファントム をオフセンタさせて静磁場中心と同様の撮像を行っ た，更に寝台上に方眼紙を置き，ファントム中心を基 準として Fig. 3a に示す左右方向両測に $5 \mathrm{~cm}$ 間隔で $15 \mathrm{~cm}$ までファントムをオフセンタさせて静磁場中心 と同様の撮像を行った。なお, ファントムを移動させ るごとに再度ファントムのセットアップを行った。こ れらオフセンタでの撮像は $\mathrm{T}_{2} \mathrm{WI} 2 \mathrm{D}$ FSE と $\mathrm{T}_{1} \mathrm{WI}$ 3D FSPGR で行い, 静磁場中心㧍よびCT の撮像結果 との比較により, オフセンタでの幾何学的歪みの変化 を観察した。これらすべての撮像を週に 1 度の頻度で 半年間にわたり実施し，経時的な歪みの変化について 評価した。

更に撮影で得られたCT, MR 画像を ARTISCAN で解析を行った。 
Table 2 Results of mean value of geometrical distortion and mean diameter error of all measurement period for each sequence at static magnetic field

\begin{tabular}{lcccc}
\hline \hline & $\begin{array}{c}\text { Mean } \\
\text { geometrical distortion } \\
(\%)\end{array}$ & $\begin{array}{c}\text { SD of } \\
\text { geometrical distortion } \\
(\%)\end{array}$ & $\begin{array}{c}\text { Mean } \\
\text { diameter error } \\
(\mathrm{mm})\end{array}$ & $\begin{array}{c}\text { SD of mean } \\
\text { diameter error } \\
(\mathrm{mm})\end{array}$ \\
\hline $\mathrm{CT}$ & -0.06 & - & -0.11 & - \\
$\mathrm{T}_{1}$ WI 3D FSPGR & -0.24 & 0.06 & -0.46 & 0.11 \\
$\mathrm{~T}_{2}$ WI 3D FSE Cube & -0.10 & 0.08 & -0.19 & 0.15 \\
$\mathrm{~T}_{2}$ WI 2D FSE & -0.21 & 0.06 & -0.40 & 0.11 \\
\hline
\end{tabular}
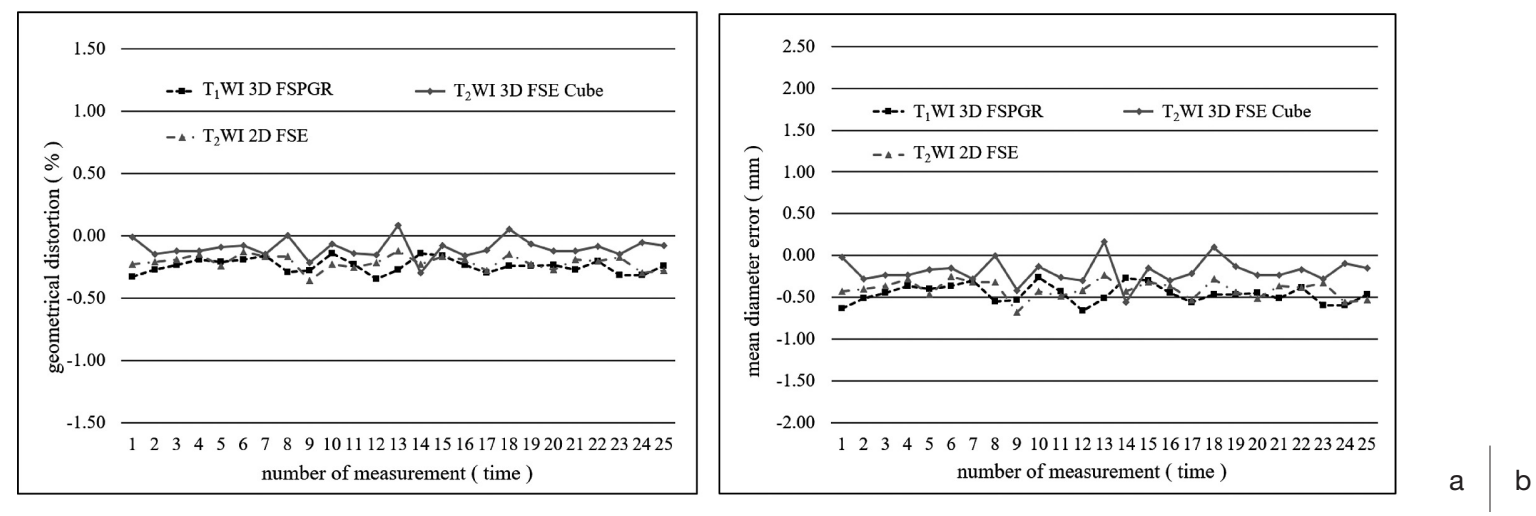

Fig. 5 Results of changes in geometrical distortion and mean diameter error during measuring period for each sequence at static magnetic field.

Changes in geometrical distortion are shown in images (a), Changes in mean diameter error in images (b).

Magphan を撮影すると Fig. 4b に示すような Axial 断面の画像が得られる。今回はこの断面の画像を用い て幾何学的な歪みを測定した。まずCT, MRIで撮影 した各画像上で, Fig. 4bのように Magphanの直径を 4 カ所のファントム直径の測定により求めた。求めた 4 力所の直径と公称值を用いて以下の式により幾何学 的歪み率 (Geometrical distortion) と径誤差 (Mean Diameter error)を算出した.

Geometrical distortion $(\%)=\frac{\varphi_{\text {mean }}-\varphi_{\text {actual }}}{\varphi_{\text {mean }}} \times 100 \quad \cdots(1)$

Mean Diameter $\operatorname{error}(m m)=\varphi_{\text {mean }}-\varphi_{\text {actual }}$

Magphanの直径の公称值を $\varphi_{\text {actual }}, 4$ 力所の測定値 の平均を $\varphi_{\text {mean }}$ とした。歪みに関してはAAPM の task group (TG) 1 Report NO 1008) で放射線治療計画 用 MRI としての許容值を上記の式(1)，(2)を用いた值 でそれぞれ $2.0 \%, 2.0 \mathrm{~mm}$ と定められている. ARTISCAN の自動解析にて計測される值は上記の式 (1), (2) とは計算式が異なるため, この許容值と測定 值の比較ができるように今回はファントム直径の測定 のみを ARTISCAN で行い, 各評価指標の算出は上記 の式(1)，(2)を用いて行った。また, 測定期間中の值
の経時的な変化を表す指標として, 幾何学的歪み率と 径誤差の標準偏差を求めた。

\section{2. 結 果}

\section{2-1 ARTISCAN の解析精度の評価}

一般的な測定方法である NEMA 法でのファントム 直径は, 4 カ所すべてで $189.5 \mathrm{~mm}$, 幾何学的歪み率 -0.26\%であった. 一方, Magphan での測定結果は, ファントム直径が最大 $190.06 \mathrm{~mm}$, 最小 $189.35 \mathrm{~mm}$, 平均 $189.83 \mathrm{~mm}$, 幾何学的歪み率が-0.09\%であった. それぞれの測定方法でのファントム直径の差は最大 $0.56 \mathrm{~mm}$, 幾何学的歪み率で $0.17 \%$ となった.

\section{2-2 幾何学的歪みの経時的な変化の評価}

Table 2 に静磁場中心でのすべての撮像条件におけ る歪み率および径誤差の全期間の平均值と標準偏差, ならびに CT との比較結果を, Fig. 5 に静磁場中心に おける各撮像条件での歪み率および径誤差の全測定 データを示す。 Table 2 より，静磁場中心においては いずれのシーケンスでもファントムサイズの縮小がみ られ， $\mathrm{T}_{1}$ WI 3D FSPGR のとき最大で歪み率：-0.24\%, 径誤差 : $-0.46 \mathrm{~mm}$ であった。 また, 歪み率と径誤差の 
Table 3 Results of mean value of geometrical distortion and mean diameter error of all measurement period for $\mathrm{T}_{2}$ WI 2D FSE at off-center position

\begin{tabular}{lcccc}
\hline \hline & $\begin{array}{c}\text { Mean } \\
\text { geometrical distortion } \\
(\%)\end{array}$ & $\begin{array}{c}\text { SD of } \\
\text { geometrical distortion } \\
(\%)\end{array}$ & $\begin{array}{c}\text { Mean } \\
\text { diameter error } \\
(\mathrm{mm})\end{array}$ & $\begin{array}{c}\text { SD of mean } \\
\text { diameter error } \\
(\mathrm{mm})\end{array}$ \\
\hline CT & -0.06 & - & -0.11 & - \\
center (T2WI 2D FSE) & -0.23 & 0.04 & -0.43 & 0.07 \\
S 5 cm offset* & -0.13 & 0.03 & -0.24 & 0.07 \\
S 10 cm offset* & 0.01 & 0.04 & 0.02 & 0.08 \\
S 15 cm offset* & 0.60 & 0.04 & 1.15 & 0.08 \\
R 5 cm offset* & -0.17 & 0.04 & -0.32 & 0.07 \\
R 10 cm offset* & -0.03 & 0.04 & -0.06 & 0.08 \\
R 15 cm offset* & 0.46 & 0.38 & 0.88 & 0.72 \\
L 5 cm offset* & -0.24 & 0.05 & -0.45 & 0.09 \\
L 10 cm offset* & -0.26 & 0.04 & -0.49 & 0.08 \\
L 15 cm offset* & -0.59 & 0.31 & -1.11 & 0.57 \\
\hline
\end{tabular}

*Acquisition data of $\mathrm{T}_{2}$ WI 2D FSE.

$\mathrm{S}$ : superior direction, R: right direction, $\mathrm{L}$ : left direction

Table 4 Results of mean value of geometrical distortion and mean diameter error of all measurement period for $\mathrm{T}_{1}$ WI $3 \mathrm{D}$ FSPGR at static magnetic field

\begin{tabular}{lcccc}
\hline \hline & $\begin{array}{c}\text { Mean } \\
\text { geometrical distortion } \\
(\%)\end{array}$ & $\begin{array}{c}\text { SD of } \\
\text { geometrical distortion } \\
(\%)\end{array}$ & $\begin{array}{c}\text { Mean } \\
\text { diameter error } \\
(\mathrm{mm})\end{array}$ & $\begin{array}{c}\text { SD of mean } \\
\text { diameter error } \\
(\mathrm{mm})\end{array}$ \\
\hline CT & -0.06 & - & -0.11 & - \\
Center (T,WI 3D FSPGR) & -0.24 & 0.06 & -0.46 & 0.11 \\
S 5 cm offset* & -0.05 & 0.04 & -0.09 & 0.07 \\
S 10 cm offset* & 0.05 & 0.03 & 0.09 & 0.06 \\
S 15 cm offset* & 0.13 & 0.05 & 0.24 & 0.10 \\
R 5 cm offset* & -0.21 & 0.05 & -0.40 & 0.10 \\
R 10 cm offset* & -0.05 & 0.04 & -0.10 & 0.07 \\
R 15 cm offset* & 1.02 & 0.05 & 1.96 & 0.10 \\
L 5 cm offset* & -0.24 & 0.04 & -0.46 & 0.08 \\
L 10 cm offset* & -0.27 & 0.04 & -0.51 & 0.08 \\
L 15 cm offset* & -0.87 & 0.04 & -1.63 & 0.08 \\
\hline
\end{tabular}

*Acquisition data of $\mathrm{T}_{1}$ WI $3 \mathrm{D}$ FSPGR.

$\mathrm{S}$ : superior direction, R: right direction, L: left direction

標準偏差は，T 2 WI 3D FSE Cube のとき最大となり， 歪み率の標準偏差：0.08\%, 径誤差の標準偏差 : 0.15 $\mathrm{mm}$ であった. Figure 5 より各測定データでみると, $\mathrm{T}_{2} \mathrm{WI} 2 \mathrm{D}$ FSE のとき最大で, 歪み率：-0.36\%, 径誤 差 : $-0.68 \mathrm{~mm}$ であった.

続いて Table 3 にオフセンタにおける $\mathrm{T}_{2} \mathrm{WI} 2 \mathrm{D}$ FSEのときの歪み率および径誤差の全期間の平均值 と標準偏差を，Table 4 にオフセンタにおける $\mathrm{T}_{1} \mathrm{WI}$ 3D FSPGRのときの歪み率および径誤差の全期間の平 均值と標準偏差を, Fig. 6 に体軸方向へのオフセンタ における両シーケンスでの歪み率, 径誤差の全測定
データを，Fig. 7 に左右方向オフセンタにおける両 シーケンスでの歪み率, 径誤差の全測定データを示 す. Table 3, 4 より, いずれのシーケンスでもオフセ ンタでは体軸方向, 左右方向ともにオフセット量が大 きくなると，体軸方向および右方向ではファントムの 拡大傾向が, 左方向ではファントムの縮小傾向がみら れた。 オフセット量 $10 \mathrm{~cm}$ 以下における全期間の平 均值は, T 1 WI 3D FSPGR での L10のときに最大で歪 み率 : $-0.27 \%$, 径誤差 : $-0.51 \mathrm{~mm}$ であった。また, 歪 み率と径誤差の標準偏差は, $\mathrm{T}_{1} \mathrm{WI} 3 \mathrm{D}$ FSPGR におけ る R5 のとき, 最大で歪み率の標準偏差 : 0.05\%, 径誤 

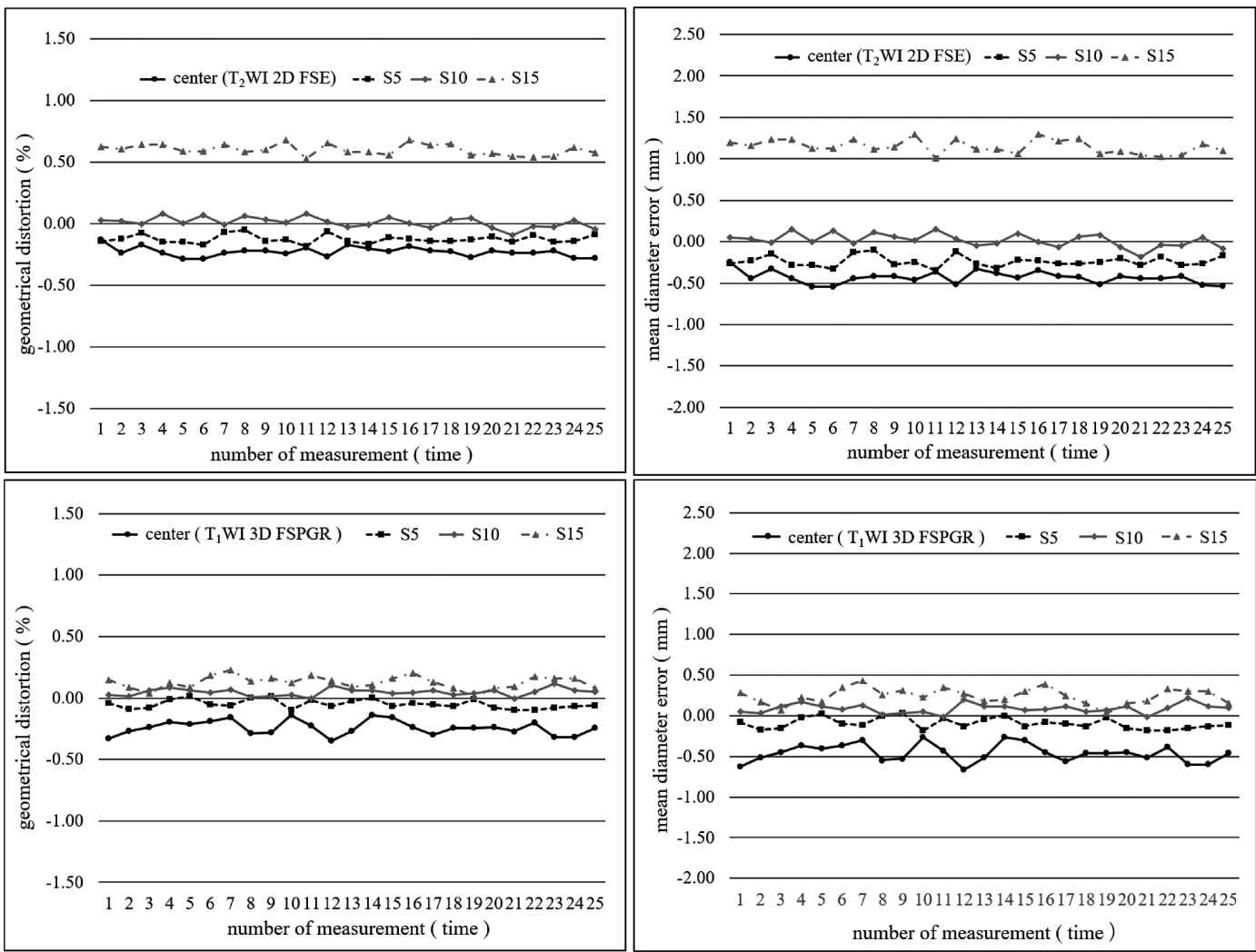

Fig. 6 Results of changes in geometrical distortion and mean diameter error during measuring period for each sequence at off-center of superior direction.

Changes in geometrical distortion and mean diameter error for $T_{2}$ WI 2D FSE are shown in images $(a, b)$. Changes in geometrical distortion and mean diameter error for $\mathrm{T}_{1}$ WI 3D FSPGR are shown in images (c, d).
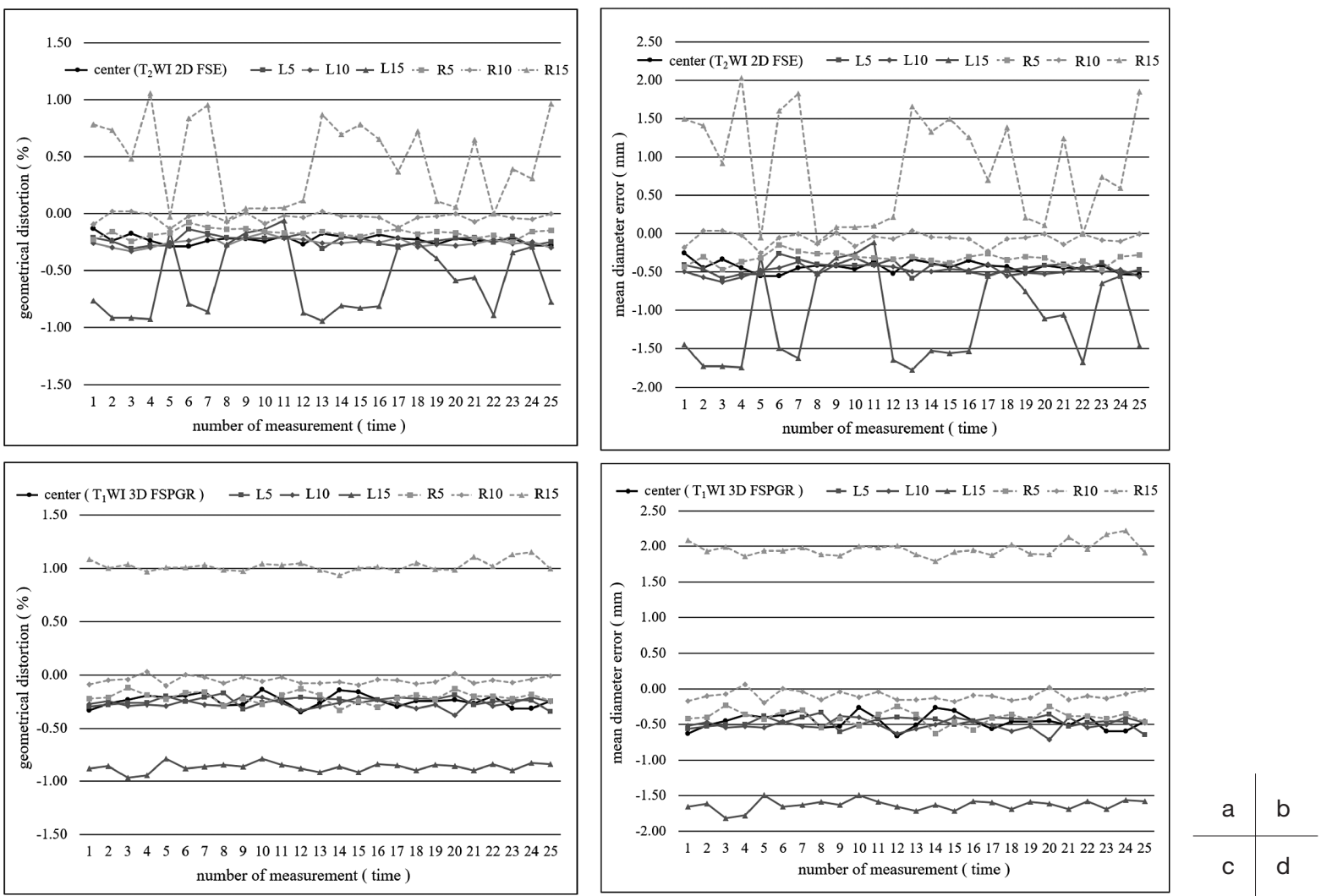

Fig. 7 Results of changes in geometrical distortion and mean diameter error during measuring period for each sequence at off-center of right-left direction.

Changes in geometrical distortion and mean diameter error for $T_{2}$ WI 2D FSE are shown in images $(a, b)$.

Changes in geometrical distortion and mean diameter error for $\mathrm{T}_{1}$ WI 3 D FSPGR are shown in images (c, d). 
差の標準偏差 : $0.10 \mathrm{~mm}$ であった. 更に Fig. 6,7 より, 測定期間中の各データでファントム実サイズからの変 化をみると， T WI 3D FSPGR におけるL10 のとき， 最大で歪み率 : $-0.38 \%$, 径誤差 : $-0.72 \mathrm{~mm}$ であった. オフセット量が $15 \mathrm{~cm}$ となると歪みは大きくなり,

Table 3, 4 より, 全期間の平均值で $\mathrm{T}_{1}$ WI $3 \mathrm{D}$ FSPGR での R15 のときに最大で, 歪み率 : $+1.02 \%$, 径誤差 : $+1.96 \mathrm{~mm}$ となった。 また, 歪み率と径誤差の標準偏 差も大きくなり， T 2 WI 2D FSE におけるR R15 のとき, 最大で歪み率の標準偏差 : 0.38\%, 径誤差の標準偏差 : $0.72 \mathrm{~mm}$ となった，更に Fig. 6,7 より，測定期間中の 各データでは $\mathrm{T}_{1}$ WI 3D FSPGR での R15 のときに最 大で歪み率 : $+1.15 \%$, 径誤差 $:+2.22 \mathrm{~mm}$ の増大となった.

\section{3. 考察}

はじめに, ARTISCAN の解析は, 1-1 で先述したよ うな測定法を用いているため, ファントムの形の変化 に対応して中心位置の認識はできていたと考えられ た。また, ARTISCANの自動解析で測定された 4 カ 所の測定值の平均と NEMA 法に準じた測定結果とを 比較すると, ファントム直径で $+0.33 \mathrm{~mm}$, 幾何学的歪 み率で+0.17\% と差は小さかった。このことより,

Magphan を ARTISCAN で自動解析する本評価法は NEMA 法と差がほとんどないことを確認した。

今回用いた撮像シーケンスの違いによる歪みの変化 について, 静磁場中心では結果に大きな差はみられな かった，一般的には，エコーの収集に傾斜磁場の高速 なスイッチングを用いる gradient echo (GRE) 系の

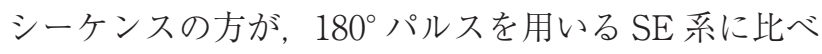
て, 歪みの原因となる磁場不均一や渦電流の影響が大 きくなりやすいといわれているが11)，今回の結果をみ るとボア中心ではその差が小さいと考えられた。

オフセンタでの撮像では, 今回用いた両撮像シーケ ンスともにオフセット量が大きくなるにつれ，体軸方 向では静磁場中心と比較して徐々にファントム径が大 きくなった. 左右方向ではオフセット量が $15 \mathrm{~cm}$ と なると, 歪みが更に大きくなった. MRIの歪みの原因 となる磁場不均一や傾斜磁場の非直線性は, 静磁場中 心から離れるほど悪化することが一般的に知られてい $ろ^{6)}$. 本検討から得られた歪みの大きさの傾向もこの 傾向と一致しており, オフセンタにおいて歪みが大き くなった原因として磁場の不均一と傾斜磁場の非直線 性が考えられた，また，本検討の目的である経時的な 変化についてみてみると, 体軸方向へオフセンタした ときは, 静磁場中心と比較して, 歪み率と径誤差の標 準偏差に大きな変化はなく, 経時的な変化はみられな
かった. 一方, 左右方向では, $15 \mathrm{~cm}$ オフセンタした ときに $\mathrm{T}_{2}$ WI $2 \mathrm{D}$ FSE での歪み率と径誤差の標準偏差 の值が, 他のシーケンスでの標準偏差の值と比較して 大きくなり, 経時的な変化が大きくなっていた. 先述 したようにARTISCAN での解析法の特徵上, ファン トムの形の変化に対応して中心位置の認識はできてい たと考えられ，ARTISCANの解析精度についても NEMA 法と差は小さく, これらのことよりARTISCAN における自動解析は再現性よく行えていたと考えられ た. 本検討ではオフセンタの撮像は SE 系のシーケン スである $\mathrm{T}_{2}$ WI $2 \mathrm{D}$ FSE と GRE 系のシーケンスであ る $\mathrm{T}_{1}$ WI 3D FSPGR の 2 種類の撮像シーケンスで実 施した．先述のように GRE 系のシーケンスでは $180^{\circ}$ パルスを用いる SE 系に比べて, 歪みの原因となる磁 場不均一や渦電流の影響が大きくなりやすいといわれ ているため, 今回べンダから提供されている歪み補正 アルゴリズムである 3D geometry correctionを併用 したこのアルゴリズムは $3 \mathrm{D}$ 撮像シーケンスのみに しか用いることができないため $\mathrm{T}_{2}$ WI 2D FSE には用 いていない.この補正アルゴリズムの効果を Torfeh $ら^{6)}$ は検討しており, axial 撮像面内に拉いて歪みが大 幅に改善されていることがわかる. 更に今回の結果で $\mathrm{T}_{2}$ WI 2D FSE と比較して $\mathrm{T}_{1}$ WI 3D FSPGR での経時 的な変化が小さくなっていたことを考えると，この補 正アルゴリズムによる補正効果が要因となって経時的 な変化が小さくなっていた可能性も示唆された。 ま た，Wyattら ${ }^{9)}$ は 3Dの歪み補正アルゴリズムを用い たシーケンスでファントムを複数回セットアップし直 した際の測定の再現性を検討しているが，その中で撮 像ごとのシミングやファントムのセットアップが全く 同一にはならないことを測定值の変化の原因として挙 げている.今回の検討とは用いている装置や撮像シー ケンスに違いはあるものの, Wyatt ら ${ }^{9)}$ の報告では, すべての撮像シーケンスで, 外れ值としている值を除 けば測定值の変化は非常に小さく，ここからも補正ア ルゴリズムが, 経時的な変化の要因となりうる撮像ご とのシミングの違いなどを補正している可能性がある と考えられた. 以上のことょり, 左右 $15 \mathrm{~cm}$ オフセン 夕したときの $\mathrm{T}_{2} \mathrm{WI} 2 \mathrm{D}$ FSE でみられた経時的な変化 の原因は, 測定方法や解析方法が原因となっているわ けではなく、シミングなどの測定ごとの装置性能の変 化と考えられ，歪み補正アルゴリズムがその影響を小 さくしていた可能性があると考えられた.

全測定期間中でみられた最大のエラーは, 右方向へ $15 \mathrm{~cm}$ オフセットしたときにみられ，ファントム径で +2.22 mmであった. AAPM Report NO 1008) では実 
際のファントム径と比較して歪み率で $2.00 \%$, 径誤差 で $2.00 \mathrm{~mm}$ 以内の誤差を治療計画用 MRI に要求して いるが，その測定範囲については FOV 全体としか記 されていない．本検討では左右方向への移動量をファ ントム中心の移動量としているため, 実際には左右 10 $\mathrm{cm}$ オフセンタでボア中心から $19.5 \mathrm{~cm}, 15 \mathrm{~cm}$ オフセ ンタでは $24.5 \mathrm{~cm}$ までの範囲を測定した結果となって いる. Walker ら ${ }^{12)}$ は治療計画体位での CT 画像よ $り$, 頭頸部や前立腺, 肺, 乳房など, 横断面内でのさ まざまな解剖学的構造物の位置をボア中心からの距離 で算出し, 測定した歪みの位置関係との比較検討をし ており，それによると乳房以外の構造物はボア中心か ら $20 \mathrm{~cm}$ 以内に存在している。これらのことを踏ま えて今回の測定結果をみると, ボア中心から左右 20 $\mathrm{cm}$ までの範囲では AAPM の許容值を満たしていた。

以上のことょり, 幾何学的歪みの経時的な変化の把 握において, 静磁場中心での評価より, 経時的な変化 が大きくなったオフセンタでの評価がより重要である と考えられた。 そして, Torfeh $ら^{6)}$ やWalker $~^{12)}$ の 報告にもあるように，オフセンタにおいてはシーケン スによって歪みの大きさが変化するという報告もある ため, 自施設で使用するシーケンスでのオフセンタも 含めた評価が必要と考えられた。 そして, 治療計画用 MRI としての幾何学的歪みに関する QA は, オフセ ンタでの評価も含めて定期的に行い, 定めた許容值を 超える歪みが生じるかどうかを管理していく必要があ ると示唆された。

最後に, 本研究のリミテーションとして, 以下に示 すことが挙げられる。 まず一つ目として, 今回使用し た Magphan はさまざまな画像特性を測定するために 複数の測定モジュールが挿入されているため, 歪みを 測定する部分もファントム内の一部分となっている. そのため, オフセンタ測定の際はファントムを再設置 する必要性があり, 本実験では I 方向ならびに, ファ ントム再設置の際の位置再現性を担保することの困難 さから AP 方向のオフセンタ評価を行っていない. ま た, 二つ目として, ARTISCAN の解析精度の検討に
て, ファントムに歪みが生じた際に NEMA 法では ファントム中心を通るような内径測定が困難となるた め, 静磁場中心のみでの検討結果となっていることが 挙げられる.オフセンタでは歪みが大きくなるため, 本来であればオフセンタでも解析精度の検討を行うこ とが望ましいと考える. そして最後に, 近年可能に なった MRI only simulation など, 視野辺縁までの歪 みのない画像が要求される場合には局所的な評価も含 めた更なる検討が必要になると思われる13).

\section{4. 結 語}

今回の測定結果より ARTISCAN を用いたファント ム径の測定は, 4 カ所の測定值の平均で NEMA 法と 比較すると, ファントム直径で $0.33 \mathrm{~mm}$, 幾何学的歪 み率で $0.09 \%$ であり, その差は小さかった. $10 \mathrm{~cm}$ の オフセンタ(ボア中心から $19.5 \mathrm{~cm}$ の範囲)では, 径誤 差ならびに歪み率において AAPM Report NO 100 の 許容值を超えるエラーがみられなかったが, 左右方向 $15 \mathrm{~cm}$ のオフセンタ(ボア中心から $24.5 \mathrm{~cm}$ の範囲) で は, オフセンタ評価に用いた $\mathrm{T}_{2}$ WI $2 \mathrm{D} \mathrm{FSE}$ および $\mathrm{T}_{1}$ WI 3D FSPGR のどちらのシーケンスにおいても測定 結果の経時的変化が大きくなり，一部許容值を超える 歪みが生じていた，そのため幾何学的歪みに関する装 置のQA は, 定期的に行う必要があり, 歪みが許容值 を超えないか確認していく必要があると示唆された. また, 治療対象となる解剖学的構造物のボア中心から の距離と歪みの関係性も, MR 画像を治療計画に用い る上では重要となるため, オフセット量と歪みの関係 性も把握しておく必要がある。

本研究の要旨は第 46 回日本放射線技術学会秋季学 術大会 (2018 年, 仙台)にて発表した。

\section{利益相反}

筆頭著者および共著者全員に開示すべき利益相反は ない.

\section{参考文献}

1）森 美雅. 定位放射線治療の求められる画像. 日独医報 2014; 59(2): 81-95.

2) Wang K, Mullins BT, Falchook AD, et al. Evaluation of PET/MRI for tumor volume delineation for head and neck cancer. Front Oncol 2017; 7: 8.

3) Wang D, Doddrell D, Cowin G. A novel phantom and method for comprehensive 3-dimensional measurement and correction of geometric distortion in magnetic resonance imaging. Magn

Reson Imaging 2004; 22(4): 529-542.

4) Janke A, Zhao H, Cowin GJ, et al. Use of spherical harmonic deconvolution methods to compensate for nonlinear gradient effects on MRI images. Magn Reson Med 2004; 52(1): 115122.

5) Pappas EP, Alshanqity M, Moutsatsos A, et al. MRI-related geometric distortions in stereotactic radiotherapy treatment planning: evaluation and dosimetric impact. Technol Cancer 
Res Treat 2017; 16(6): 1120-1129.

6) Torfeh T, Hammoud R, Perkins G, et al. Characterization of 3D geometric distortion of magnetic resonance imaging scanners commissioned for radiation therapy planning. Magn Reson Imaging 2016; 34(5): 645-653.

7）西尾禎治, 河野良介, 森慎一郎, 他. X 線治療計画システ ムに関する QA ガイドライン. 医学物理 2008; 27(Suppl 6).

8) Edward F, Michael J, Dick J, et al. Acceptance Testing and Quality Assurance Procedures for Magnetic Resonance Imaging Facilities. AAPM report No.100. 2010.

9) Wyatt J, Hedley S, Johnstone E, et al. Evaluating the repeatability and set-up sensitivity of a large field of view distortion phantom and software for magnetic resonance-only radiotherapy. Phys Imaging Radiat Oncol 2018; 6: 31-38.

10) Glover GH, Pelc NJ. Method for correcting image distortion due to gradient nonuniformity. United States Patent 1983.

11）武村哲浩, 笹本耕平, 仲村香織, 他. 静磁場強度の異なる 3 機種を用いた脳定位放射線治療計画のための MRI 画像 の歪み比較. 日放技学誌 $2013 ; 69(6): 641-647$.

12) Walker A, Liney $G$, Metcalfe $P$, et al. MRI distortion: considerations for MRI based radiotherapy treatment planning. Australas Phys Eng Sci Med 2014; 37(1): 103-113.

13) Kerkmeijer LGW, Maspero M, Meijer GJ, et al. Magnetic resonance imaging only workflow for radiotherapy simulation and planning in prostate cancer. Clin Oncol 2018; 30(11): 692701. 